\author{
Geography
}

http://www.journalesgia.com

\title{
FEATURES OF SEASONAL CHANGES OF THE CASPIAN SEA LEVEL
}

\author{
Safarov E.S. ${ }^{1}$, Cretaux J.-F. ${ }^{2}$, Mammadov R.M. ${ }^{1}$, Arsen A. ${ }^{3}$, Safarov S.H. ${ }^{1}$ \\ ${ }^{1}$ Institute of Geography of ANAS \\ 115, H.Cavid av., Baku, Azerbaijan, AZ1143: elnur.safarov@geo.az \\ ${ }^{2} \mathrm{CNES} /$ Legos \\ 14, avenue Edouard Belin, Toulouse, France, 31400 \\ ${ }^{3}$ Freelancer, Warsaw, Poland
}

Keywords: The Caspian Sea, Volga River, satellite altimetry, track, Jason 1-2, ENVISAT, amplitude, phase, sea level
Summary. The Caspian Sea is the largest closed reservoir in the world. In the absence of a direct connection with the world ocean, the closed Caspian Sea is characterized by significant secular changes, inter-annual and seasonal variability in the level. In the work, according to observations of radar altimetry of ENVISAT, Jason 1 and Jason 2 satellites, seasonal variations in the level of the Caspian Sea, as well as features of their amplitude distribution, also the phases of their appearance over the entire sea area, are investigated. According to a special method, the average annual values of the amplitude and the occurrence phase of seasonal fluctuations of water level for various areas of the sea area were calculated using pre-determined satellite tracks. The influence of the Volga River flow on the amplitude and phase of seasonal variations in the various areas of the Caspian Sea level has been studied. Studies have shown that the amplitude of seasonal fluctuations in sea level of the North Caspian Sea is greater than in the Middle and South Caspian. They also differ in direction from east to west. The earliest phases of the sea level amplitudes were recorded in the Northern Caspian, below the Volga delta (in May), and in the rest of the sea much later (June-July). It has been established that the influence of the Volga River flow is most sensitive in the northern part of the sea, and towards the south its influence gradually decreases, and other factors start to prevail (evaporation, precipitation). The paper discusses the reasons for this difference.

(C) 2018 Earth Science Division, Azerbaijan National Academy of Sciences. All rights reserved.

\section{Introduction}

One of the main factors affecting to seasonal fluctuations of the Caspian Sea level is river water input (Volga, Ural, Kura, Terek, etc.). The Volga provides $78-82 \%$ of the total river input to the Caspian Sea (Гидрометеорология и гидрохимия морей, 1990). Even though other rivers have some slightly different physical-geographical conditions, the intra-annual variations of the surface waters flowing to the sea, in general correspond to intraannual river inflow of the Volga River. High water period with maximal discharge of the Volga River is observed in May and June (Fig. 1).

In order to analyze the spatial and temporal distribution of seasonal sea water level fluctuations and the influence of the river flow of the Volga River on this distribution, it is necessary to create spatial and temporal distribution maps of the sea level amplitude and phases of its occurrence for the whole surface of the Caspian Sea. However, it is impossible to solve this problem according to the insitu observations, because they cover only coastal regions. Thus, for this purpose it is more expedient to use remote sensing data, which are much attractive in case when contact measurements cannot be conducted because of geographic, political or economic reasons (Troitskaya et al., 2011).

Since the launch of Topex/Poseidon in 1992 many studies have shown the high potential of radar altimetry for the monitoring of lake height variations (Birkett, 1995; Coe and Birkett, 2004; Aladin et al., 2005; Crétaux et al., 2005; Hwang et al., 2005; Crétaux and Birkett, 2006; Crétaux et al., 2009; Crétaux et al., 2011b; Hwang et al., 2011; Lee et al., 2011; Gao et al., 2012; Zheng and Bastiaanssen, 2013; Arsen et al., 2015; Chen et al., 2017). The main advantages of this remote sensing method is global coverage and high penetrating ability of radio waves through the atmosphere and clouds. This 
allows to perform investigation practically in all weather conditions, as well as in condition of the presence of sufficiently high aerosol concentrations in the air (Troitskaya et al., 2011). For the Caspian Sea satellite radar altimetry data were successfully used since Topex/Poseidon launch in 1993 (Kouraev et al., 2011). However, taking into account the temporal variability of the water regime of the Caspian Sea, it is of great interest to study sea level amplitude and phase distribution using recent data of Jason 2. It should be taken into consideration that the satellites of the Jason series have an advantage in the frequency of data repetition, and the ENVISAT satellite is preferable regarding the density of track distribution over the sea's water area. The accuracy of measuring by Jason satellites over the oceans is $2 \mathrm{~cm}$ (Fu et al., 2001), but the error in calculating the altitude of the sea surface in relation to the reference ellipsoid reaches $4.2 \mathrm{~cm}$ (Chelton et al., 2001). The accuracy of measurements by ENVISAT vary depending on target size (Arsen et al., 2015) and is generally $4-5 \mathrm{~cm}$ for big open water bodies (Crétaux et al., 2011a; Lebedev et al., 2005).

\section{Used material and research methodology}

The satellite altimetry observation data of ENVISAT (2002-2009) GDR v2, Jason 1 (2002-2009) GDR-C and Jason 2 (2008-2013) GDR-D data used in this work were obtained from Centre of Topography of the Oceans and the Hydrosphere (ctoh.legos.obs-mip.fr) and processed in collaboration with LEGOS/ECHOS research group (www.legos.obs-mip.fr).

The Caspian Sea surface intersects with 8 Jason 1-2-3 tracks (016, 031, 057, 092, 107, 133, 168, 209 and 244). Four of them are ascending, and 4 descending (Fig. 2). The revisit time for each of these tracks is about 10 (9.9156) days. The longest track (092) is about $1000 \mathrm{~km}$ long and crosses the sea from Iranian coast in the South to the southern boundary of the Volga Delta (territory of the Russian Federation) in the North. The Caspian Sea intersects with 25 tracks of the ENVISAT satellite as well. Of these, 14 are ascending, and 11 are descending. The revisit time for each of these tracks was about 35 days. The gaps between ENVISAT tracks are smaller then that of Jason 1, Jason 2 which allow us to retrieve more information about the distribution of seasonal sea-level amplitudes and their phases of occurrence throughout the water area.

In order to identify the annual maximum amplitudes and their phases of occurrence in the entire water area of the Caspian Sea, an integrated research along the corresponding tracks, consisting of three stages was carried out.
In the first stage, satellite data for the Jason 1, Jason 2 and ENVISAT were geographically delimited. For each track for each satellite the sea level was calculated using LEGOS processing chain which was described by Cretaux et al., 2011a. The sea level is calculated as follows:

$$
\mathrm{SSH}=\text { altitude }- \text { corrected range, }
$$

where SSH is the sea surface height, altitude is the satellite orbit, and corrected range is the measured range with atmospheric path delay and geophysical corrections. The expression for the sea level anomaly is as follows:

$$
\text { SLA }=\text { SSH }- \text { MSS, }
$$

where SLA is the sea level anomaly, and MSS is the mean sea surface.

In an open sea and in the ocean, estimation of sea level is usually done with averaged $1 \mathrm{~Hz}$ data. For the Caspian Sea the averaging of the sea level was carried out over $10 \mathrm{~km}$ strips. Outliners inside each patch were filtered using a 3-sigma test.

At the second stage of the study the spatial and temporal distribution of sea level is analyzed. For each satellite for each track, the $10 \mathrm{~km}$ averaged sea level time series are used to determine annual mean, annual maximum and minimum values of the sea level anomalies and phase (the day of the year of their occurrence). Here, the definition of the amplitude is considered as half of the difference between the maximum and minimum level anomalies, observed in one year. For each $10 \mathrm{~km}$ patch the average multi-annual amplitudes and the phases were also calculated.

Finally, after the completion of the first and second stages of the studies, based on satellite altimetry observations data maps of the distribution of the mean annual maximum amplitudes and the phases of their occurrence throughout the all water area were created using ArcGIS 10.3 (Fig. 2 and 3).

\section{Results and discussions}

Fig. 1 reflects monthly distribution of the Volga River water discharge based on in-situ observation data, conducted from measurement point Verkhnee Lebyazhye during 2002-2013. As seen, the value of the river flow begins to grow in March and reaches the maximum in May. Despite the fact that the maximum water discharge in Volga is observed in May, the spatial variability of the amplitude and phases of sea level observations indicate the complexity of these changes (Fig. 2 and 3). 
According to the data taken from Jason 1 and Jason 2 satellites for the 2002-2013 period of observations, the largest amplitudes $(43-48 \mathrm{~cm})$ of seasonal sea level changes (Fig. 2a) were observed in the eastern part of the North Caspian (track 133) from June 25 to July 5 (Fig. 2b). In the Northern Caspian, south to the Volga Delta (tracks 57 and 168), relatively high values $(33-38 \mathrm{~cm})$ of amplitude in the sea level were also observed (Fig. 2a) from mid-May to early June (Fig. 2b). The relatively bigger values of the seasonal sea level fluctuations amplitude, can be explained by the enormous influence of the flow from the Volga and Ural rivers, as well as such factors as the shallow waters, the nature of surface currents and, partially, the effect of relatively light fresh water that enters the sea with rivers discharge.

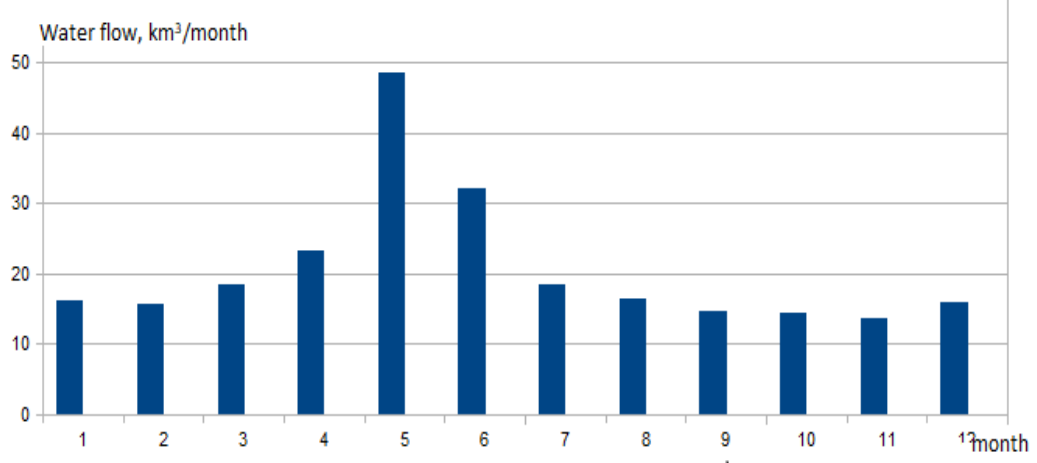

Figure 1. The histogram of intra-annual average water flow discharge of the Volga River based on the observation data for 2002-2013
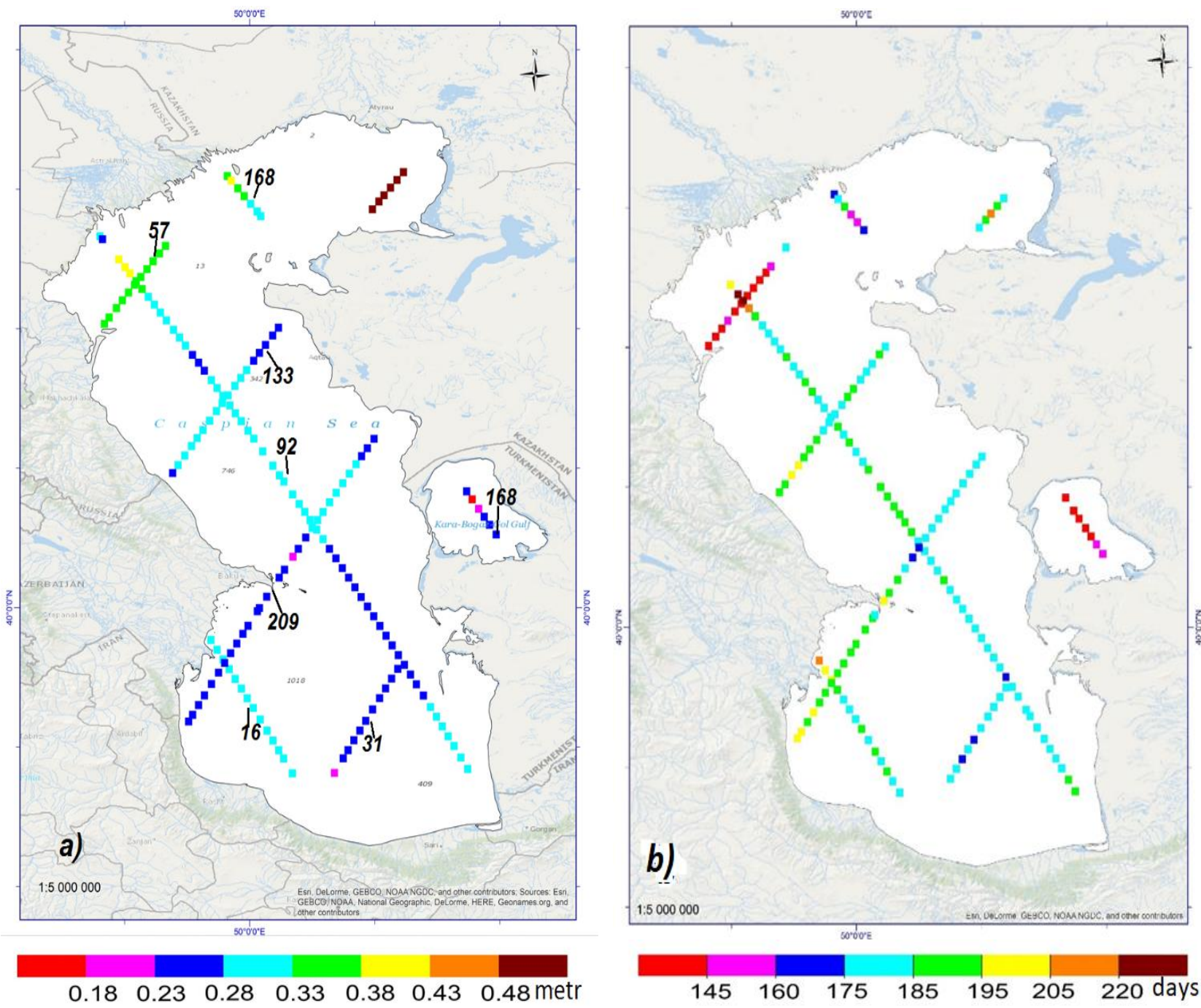

Figure 2. Distribution maps for tracks of annual level amplitudes in the Caspian Sea (a) and the phases of their occurrence (b) based on the data of the altimetry observations of the Jason 1, Jason 2 satellites for 2002-2013 

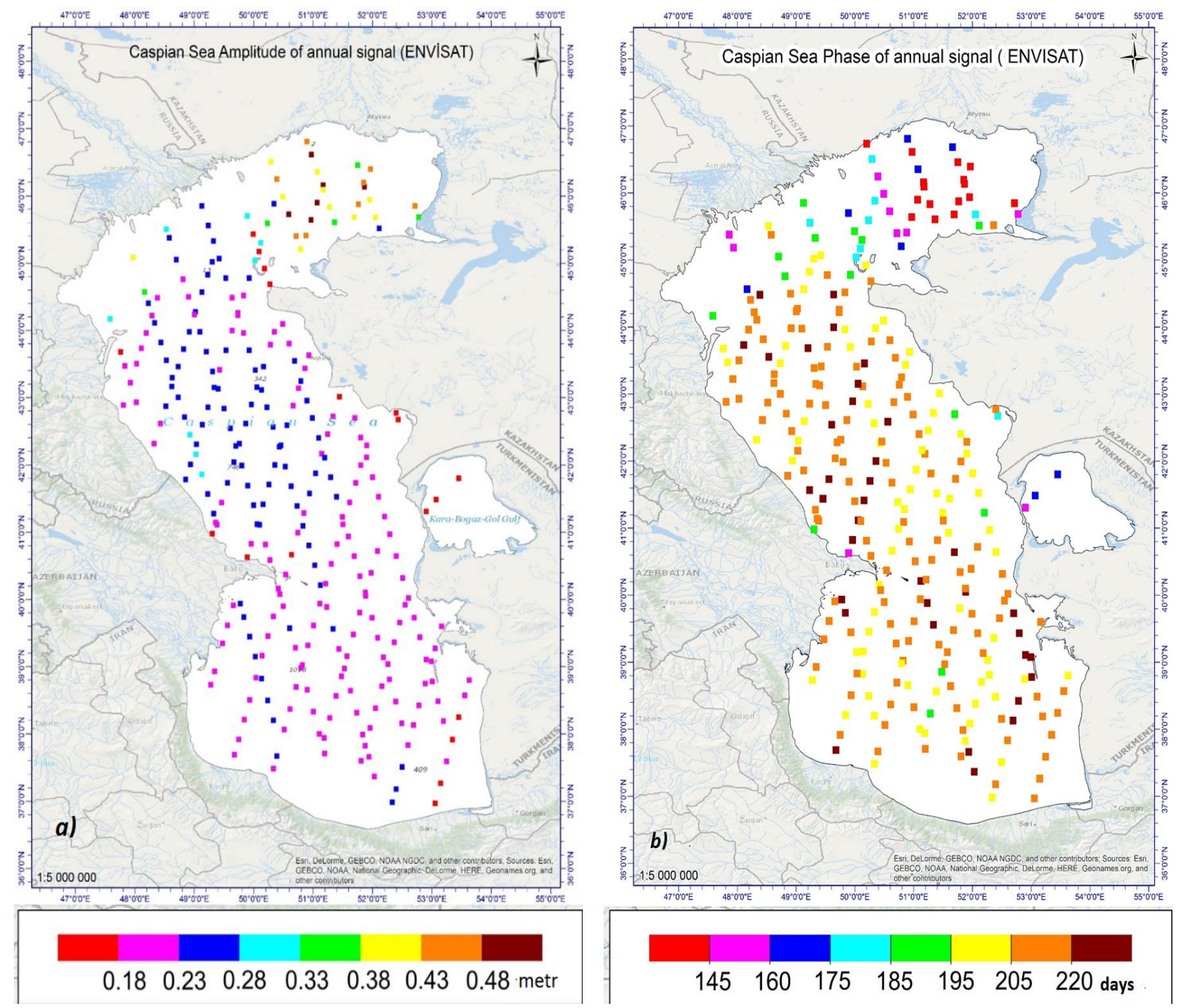

Figure 3. Maps of distribution for tracks of annual level amplitudes (a) in the Caspian Sea and the phases of their occurrence (b) based on the data of the altimetry observations of the ENVISAT satellite for 2002-2013

It should be noted that the results obtained here are slightly different from those obtained with the help of Topex/Poseidon data (Kouraev et al., 2011), where the available seasonal amplitude values are smaller, and observation phases of them are bigger. However, the comparison with the data of ground insitu stations (Abuzyarov, 2011) shows that the values of amplitudes and phases of observation, obtained in this study are much closer to the real values. This, incidentally, is also noticeable from the graphs of sea level evolution basing on data of ground and satellite observations.

In the Middle Caspian, the sea level amplitude is relatively lower than in the Northern Caspian. Along the track 092 in the deep-water areas, it varies around $28-33 \mathrm{~cm}$ (Fig. 2a). This result has a good agreement with the observation data from the coastal region stations (Abuzyarov, 2011). In the relatively northern part of the deep-water area, the phases of occurrence of the sea level amplitudes are observed from June 25 to July 5, and in the southern part - in July 5-15 (Fig. $2 b)$. The amplitude phases to the east of track number 92 are related to an earlier period, whereas to the west - on the opposite (tracks 133 and 209). If we compare with the bottom topography map, it can be concluded that in the shallow water areas of the Middle Caspian, seasonal amplitudes of the level are observed at an earlier time than in the deep waters. The reason is apparently because of warming of the sea water which causes the evaporation to increase, which prevents a further rise in sea level due to the flows of the Volga and other rivers.

In the Southern Caspian (tracks 31, 92, 209), the values of the sea level amplitude are generally getting lower values $(23-28 \mathrm{~cm})$ than in Northern and Middle Caspian regions, and only in the western part, where the Kura River flows into the sea (track 16), as well as surrounding areas it reaches the value of $28-31 \mathrm{~cm}$. In the western part of the Southern Caspian, the water level and the 
amplitude of its fluctuation is slightly bigger compared to the eastern part (Fig. 2a). This can be explained by relatively huge river flow and huge amount of atmospheric precipitation in the western part. The phases of the occurrence of sea level amplitudes in the eastern territories are observed earlier than in the western areas (Fig. $2 b)$. The reason for that probably lies in the fact that in Southern Caspian region the impact of the Volga River decreases and unlike western territories the amount of precipitation here is low, whereas evaporation is high. In other words, rapid evaporation in the eastern part of the sea leads to an earlier formation of the amplitude.

Maps of distributions of seasonal amplitudes and phases of their occurrence, obtained with the help of the altimetry observation data from the ENVISAT satellite, are shown in Fig. 3, where it can be seen that the nature of these distributions is generally similar to those obtained from the Jason 1, Jason 2 satellites (Fig. 2). However, the difference lies in the fact that the amplitudes obtained from ENVISAT data turned out to be relatively smaller, and the phases, on the contrary, are bigger than for the Jason 1, Jason 2 satellites. This can be explained by a much longer period of track repetition of the ENVISAT satellite (35 days) compared to Jason 1, Jason 2 (10 days). Longer track repetition period leads to a bigger error in establishing correct values of the amplitude of the level and the

\section{REFERENCES}

Abuzyarov Z.K. Some features of the spatio-temporal variability of the level of the Caspian Sea. Proceedings of the SHC of RF, V. 345, 2011, pp. 5-23.

Aladin N., Crétaux J.-F., Plotnikov I.S., Kouraev A.V., Smurov A.O., Cazenave A., Egorov A.N., Papa F. Modern hydrobiological state of the Small Aral Sea. Environmetrics, V. 16, Iss. 4, 2005, pp. 375-392. DOI: 10.1002/env.709.

Arsen A., Crétaux J.-F., Abarca Del Rio R. Use of SARAL/ AltiKa over Mountainous Lakes, intercomparison with Envisat mission. Marine Geodesy, V. 38, 2015, pp. 534-548. DOI: $10.1080 / 01490419.2014 .1002590$.

Birkett C.M. The contribution of TOPEX/POSEIDON to the global monitoring of climatically sensitive lakes. J. Geophys. Res., V. 100, Iss. C12, 1995, pp. 25179-25204. DOI: $10.1029 / 95 J C 02125$.

Chelton D.B., Ries J.C., Haines B.J. et al. Satellite altimetry. In: Satellite altimetry and earth sciences. A handbook of techniques and applications. L.-L.Fu and A.Cazenave (eds.), Academic Press. San Diego, USA, 2001, pp. 1-131.

Chen J.L., Pekker T., Wilson C.R., Tapley B.D., Kostianoy A.G., Cretaux J.-F., Safarov E.S. Long-term Caspian Sea level change. Geophys. Res. Lett., V. 44, Iss. 13, 2017, pp. 6993-7001. DOI.org/10.1002/2017GL073958.

Coe M.T., Birkett C.M. Calculation of river discharge and prediction of lake height from satellite radar altimetry: Example for the Lake Chad basin. Water Resour. Res., V. 40, Iss. 10, 2004, W10205. DOI: 10.1029/2003WR002543. phase of its occurrence, and therefore the measured values of the amplitude turn out to be understated, and its phases are overvalued.

\section{Conclusion}

Summarizing the results obtained from the satellite altimetry of Jason 1, Jason 2 and ENVISAT, it can be concluded that, in general, the biggest seasonal sea level amplitudes are observed in the Northern Caspian, and the smallest - in the Southern Caspian. The earliest phases of the sea level amplitudes are fixed in the Northern Caspian, below the Volga Delta (in May), and in the remaining parts of the sea - much later (in June-July). In the Middle and Southern parts of the Caspian Sea, to the east of track 92, the phases of amplitudes are observed earlier than in the western part. All this shows that in different parts of the sea, besides the impact of flow of the Volga River, the formation and distribution of phases of amplitudes are influenced also by evaporation, precipitation and short-period phenolmena (wind and related movement of water).

A comparison of the results obtained in this work with the results concluded by other authors shows that depending on the combination of various factors (river flow, evaporation, precipitation, etc.), the nature of the spatial distribution and phases of seasonal sea level amplitudes may be slightly different.

\section{ЛИТЕРАТУРА}

Abuzyarov Z.K. Some features of the spatio-temporal variability of the level of the Caspian Sea. Proceedings of the SHC of RF, V. 345, 2011, pp. 5-23.

Aladin N., Crétaux J.-F., Plotnikov I.S., Kouraev A.V., Smurov A.O., Cazenave A., Egorov A.N., Papa F. Modern hydrobiological state of the Small Aral Sea. Environmetrics, V. 16, Iss. 4, 2005, pp. 375-392. DOI: 10.1002/env.709.

Arsen A., Crétaux J.-F., Abarca Del Rio R. Use of SARAL/ AltiKa over Mountainous Lakes, intercomparison with Envisat mission. Marine Geodesy, V. 38, 2015, pp. 534-548. DOI: $10.1080 / 01490419.2014 .1002590$.

Birkett C.M. The contribution of TOPEX/POSEIDON to the global monitoring of climatically sensitive lakes. J. Geophys. Res., V. 100, Iss. C12, 1995, pp. 25179-25204. DOI: 10.1029/95JC02125.

Chelton D.B., Ries J.C., Haines B.J. et al. Satellite altimetry. In: Satellite altimetry and earth sciences. A handbook of techniques and applications. L.-L.Fu and A.Cazenave (eds.), Academic Press. San Diego, USA, 2001, pp. 1-131.

Chen J.L., Pekker T., Wilson C.R., Tapley B.D., Kostianoy A.G., Cretaux J.-F., Safarov E.S. Long-term Caspian Sea level change. Geophys. Res. Lett., V. 44, Iss. 13, 2017 , pp. 6993-7001. DOI.org/10.1002/2017GL073958.

Coe M.T., Birkett C.M. Calculation of river discharge and prediction of lake height from satellite radar altimetry: Example for the Lake Chad basin. Water Resour. Res., V. 40, Iss. 10, 2004, W10205. DOI: 10.1029/2003WR002543. 


\section{Geography}

Crétaux J.-F., Calmant S., Abarca Del Rio R. et al. Lakes studies from satellite altimetry. In: Handbook on Coastal altimetry. Springer. Ch. 19, 2011a, pp. 509-513.

Crétaux J.-F., Jelinski W., Calmant S., Kouraev A., Vuglinski V., Bergé-Nguen M., Gennero M.C. et al. SOLS: A lake database to monitor in the Near Real Time water level and storage variations from remote sensing data. Advances in Space Research, Elsevier. V. 47, Iss. 9, 2011b, pp. 1497 1507. DOI:10.1016/j.asr.2011.01.004.

Crétaux J.-F., Kouraev A.V., Papa F., Bergé M.N., Cazenave A., Aladin N., Plotnikov I.S. Evolution of sea level of the Big Aral Sea from satellite altimetry and its implications for water balance. Journal of Great Lakes Research, V. 31, Iss. 4, 2005, pp. 520-534. DOI: 10.1016/S0380-1330(05)70281-1.

Crétaux J.-F., Birkett C. Lake studies from satellite radar altimetry. Comptes Rendus Geoscience, V. 338, Iss.14-15, 2006, pp. 1098-1112. DOI: 10.1016/j.crte.2006.08.002.

Crétaux J.-F., Calmant S., Romanovski V., Shabunin A., Lyard F., Bergé M., Cazenave A., Hernandez F., Perosanz F. An absolute calibration site for radar altimeters in the continental domain: Lake Issykkul in Central Asia. J. Geod., V. 83, Iss. 8, 2009, pp. 723-735. DOI: 10.1007/s 00190-008-0289-7.

Fu L.-L., Cazenave A. Satellite altimetry and Earth science. A handbook of techniques and applications. International Geophysics Series, Academic press. V. 69, 2001, 463 p.

Gao H., Birkett C., Lettenmaier D.P. Global monitoring of large reservoir storage room satellite remote sensing. Water Resour. Res., V. 48, Iss. 9, 2012, W09504. DOI: 10.1029/ 2012WR012063.

Hydrometeorology and hydrochemistry of the seas. Project "The Seas". V. 6 - Caspian Sea. Issue 1 - Hydrometeorological conditions. F.S. Terzieva, A.N. Kosareva and A.A. Kerimov (eds.). Gidrometeoizdat. St.-Petersburg, 1990, 359 p. (in Russian).

Hwang C., Kao Y., Natthachet T. A preliminary analysis of lake level and water storage changes over lakes Baikal and Balkhash from satellite altimetry and gravimetry. Terrestrial, Atmospheric and Oceanic Sciences, V. 22, № 2, 2011, pp. 97-108. DOI: 10.3319/TAO.2010.05.19.01(TibXS).

Hwang C., Peng M., Ning J., Luo J., Sui C. Lake level variations in China from TOPEX/Poseidon altimetry: data quality assessment and links to precipitation and ENSO. Geophysical Journal International, V. 161, Iss. 1, 2005, pp. 1-11. DOI: 10.1111/j.1365-246X.2005.02518.x.

Kouraev A.V., Crétaux J.-F., Lebedev S.A. et al. Satellite altimetry applications in the Caspian Sea. In: Handbook on Coastal altimetry. S.Vignudelli, A.G.Kostianoy, P.Cipollini, J.Benveniste (eds.). Springer Berlin Heiderberg. ch. 13, 2011, pp. 331-366.

Lebedev S.A., Kostianoy A.G. Satellite altimetry of the Caspian Sea. Publisher "More". Intern. Institute of the Ocean. Moscow, 2005, 366 p. (in Russian).

Lee H., Shum C.K., Tseng K-H., J. Guo, C.-Y. Kuo. Present-day lake level variation from Envisat altimetry over the Northeastern Qinghai-Tibetan Plateau: links with precipitation and temperature. Terrestrial, Atmospheric and Oceanic Sciences, V. 22, Iss. 2, 2011, pp. 169-175. DOI: 10.3319/ TAO.2010.08.09.01(TibXS).

Troitskaya Yu.I., Balandina G.N., Rybushkina G.V., Soustova I.A., Kostyanoy A.G., Lebedev S.A., Panyutin A.A., Filina L.V. Investigations of the water level variability in the Gorky reservoir on the basis of satellite altimetry data. Research of the Earth from Space, № 1, 2011, pp. 48-56.

Zheng Duan, Bastiaanssen W.G.M. Estimating water volume variations in lakes and reservoirs from four operational satellite altimetry databases and satellite imagery data. Remote Sensing of Environment, V. 134, 2013, pp. 403-416. DOI: 10.1016/j.rse.2013.03.010.
Crétaux J.-F., Calmant S., Abarca Del Rio R. et al. Lakes studies from satellite altimetry. In: Handbook on Coastal altimetry. Springer. Ch. 19, 2011a, pp. 509-513.

Crétaux J.-F., Jelinski W., Calmant S., Kouraev A., Vuglinski V., Bergé-Nguen M., Gennero M.C. et al. SOLS: A lake database to monitor in the Near Real Time water level and storage variations from remote sensing data. Advances in Space Research, Elsevier. V. 47, Iss. 9, 2011b, pp. 14971507. DOI:10.1016/j.asr.2011.01.004.

Crétaux J.-F., Kouraev A.V., Papa F., Bergé M.N., Cazenave A., Aladin N., Plotnikov I.S. Evolution of sea level of the Big Aral Sea from satellite altimetry and its implications for water balance. Journal of Great Lakes Research, V. 31, Iss. 4, 2005, pp. 520-534. DOI: 10.1016/S0380-1330(05)70281-1.

Crétaux J.-F., Birkett C. Lake studies from satellite radar altimetry. Comptes Rendus Geoscience, V. 338, Iss.14-15, 2006, pp. 1098-1112. DOI: 10.1016/j.crte.2006.08.002.

Crétaux J.-F., Calmant S., Romanovski V., Shabunin A., Lyard F., Bergé M., Cazenave A., Hernandez F., Perosanz F. An absolute calibration site for radar altimeters in the continental domain: Lake Issykkul in Central Asia. J. Geod., V. 83, Iss. 8, 2009, pp. 723-735. DOI: 10.1007/s 00190-008-0289-7.

Fu L.-L., Cazenave A. Satellite altimetry and Earth science. A handbook of techniques and applications. International Geophysics Series. Academic press. V. 69, 2001, 463 p.

Gao H., Birkett C., Lettenmaier D.P. Global monitoring of large reservoir storage room satellite remote sensing. Water Resour. Res., V. 48, Iss. 9, 2012, W09504. DOI: 10.1029/ 2012WR012063.

Hwang C., Kao Y., Natthachet T. A preliminary analysis of lake level and water storage changes over lakes Baikal and Balkhash from satellite altimetry and gravimetry. Terrestrial, Atmospheric and Oceanic Sciences, V. 22, № 2, 2011, pp. 97-108. DOI: 10.3319/TAO.2010.05.19.01(TibXS).

Hwang C., Peng M., Ning J., Luo J., Sui C. Lake level variations in China from TOPEX/Poseidon altimetry: data quality assessment and links to precipitation and ENSO. Geophysical Journal International, V. 161, Iss. 1, 2005, pp. 1-11. DOI: 10.1111/j.1365- 246X.2005.02518.x.

Kouraev A.V., Crétaux J.-F., Lebedev S.A. et al. Satellite altimetry applications in the Caspian Sea. In: Handbook on Coastal altimetry. S.Vignudelli, A.G.Kostianoy, P.Cipollini, J.Benveniste (eds.). Springer Berlin Heiderberg. ch. 13, 2011, pp. 331-366.

Lee H., Shum C.K., Tseng K-H., J. Guo, C.-Y. Kuo. Present-day lake level variation from Envisat altimetry over the Northeastern Qinghai-Tibetan Plateau: links with precipitation and temperature. Terrestrial, Atmospheric and Oceanic Sciences, V. 22, Iss. 2, 2011, pp. 169-175. DOI: 10.3319/ TAO.2010.08.09.01(TibXS).

Troitskaya Yu.I., Balandina G.N., Rybushkina G.V., Soustova I.A., Kostianoy A.G., Lebedev S.A., Panyutin A.A., Filina L.V. Investigations of the water level variability in the Gorky reservoir on the basis of satellite altimetry data. Research of the Earth from Space, № 1, 2011, pp. 48-56.

Zheng Duan, Bastiaanssen W.G.M. Estimating water volume variations in lakes and reservoirs from four operational satellite altimetry databases and satellite imagery data. Remote Sensing of Environment, V. 134, 2013, pp. 403-416. DOI: 10.1016/j.rse.2013.03.010.

Гидрометеорология и гидрохимия морей (под ред. Ф.С. Терзиевой, А.Н. Косаревой, А.А. Керимова). Том 6 - Каспийское море. Вып. 1 - Гидрометеорологические условия. Гидрометеоиздат. Санкт-Петербург, 1990, 359 с.

Лебедев С.А., Костяной А.Г. Спутниковая альтиметрия Каспийского моря. Издательский центр «МОРЕ» Международного института океана. Москва, 2005, 366 с. 


\title{
ОСОБЕННОСТИ СЕЗОННЫХ ИЗМЕНЕНИЙ УРОВНЯ КАСПИЙСКОГО МОРЯ
}

\author{
Сафаров Э.С. ${ }^{1}$, Крето Ж.-Ф. ${ }^{2}$, Мамедов Р.М. ${ }^{1}$, Арсен А. ${ }^{3}$, Сафаров С.Г. \\ ${ }^{1}$ Институт Географии НАНА \\ AZ1143, г.Баку, просn. Г.Джавида, 115: elnur.safarov@geo.ab.az \\ ${ }^{2}$ CNES/Legos \\ 31400, Францฺия, Тулуза, просп.Эдуарда Белин,14 \\ ${ }^{3}$ Freelancer \\ Вариава, Польиа
}

\begin{abstract}
Резюме. Каспийское море является самым большим закрытым водоемом во всем мире. В отсутствии непосредственной связи с мировым океаном замкнутому Каспийскому морю свойственны значительные вековые, межгодовые и сезонные изменения уровня. В работе по данным наблюдений радиолокационной альтиметрии спутников ENVISAT, Jason 1 и Jason 2 рассматриваются сезонные колебания уровня Каспийского моря, особенности распределения их амплитуды, а также фазы появления по всей акватории моря. По специальной методике рассчитаны среднегодовые значения амплитуды и фазы появления сезонных колебаний уровня воды для различных районов акватории моря по заранее установленным спутниковым трекам. Изучено влияние стока реки Волга на амплитуду и фазу сезонных колебаний уровня различных районов Каспийского моря. Исследования показали, что в Северном Каспии значение амплитуды сезонных колебаний уровня моря больше, чем в Среднем и Южном Каспии. Они также отличаются в направлении с востока на запад. Самые ранние фазы амплитуд уровня моря зафиксированы в Северном Каспии, ниже дельты Волги (в мае), а в остальных частях моря - значительно позже (июнь-июль). Установлено, что влияние стока реки Волга наиболее чувствительно в северной части моря, а в направлении к югу оно постепенно уменьшается, и начинает преобладать воздействие других факторов (испарение, атмосферные осадки). В работе обсуждаются причины такого различия.
\end{abstract}

Ключевые слова: Каспийское море, Волга река, спутниковая альтиметрия, трек, Jason 1-2, ENVISAT, амплитуда, фаза, уровень моря

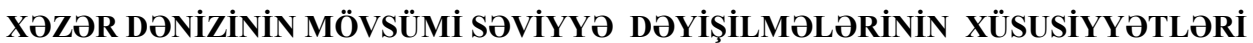

\author{
Səfərov E.S. ${ }^{1}$, Kreto J.-F. ${ }^{2}$, Məmmədov R.M. ${ }^{1}$, Arsen A. ${ }^{3}$, Səfərov S.H. ${ }^{1}$ \\ ${ }^{I}$ AMEA Coğrafiya Institutu, \\ AZ1143, Bakl şəh., H.Cavid prosp., 115: elnur.safarov@geo.ab.az \\ ${ }^{2}$ CNES/Legos \\ 31400, Fransa, Tuluza, av. Edouard Belin, 14 \\ ${ }^{3}$ Freelancer \\ Varşava, Polşa
}

Xülasə. Məlum olduğu kimi, Xəzər dənizi dünyanın ən böyük qapalı su hövzəsidir. Dünya okeanı ilə birbaşa əlaqəsi olmayan qapalı Xəzər dənizi əhəmiyyətli səviyyə dəyişilmələri (əsrlik, illərarası və mövsümi) ilə xarakterizə olunur. Məqalə Xəzər dənizi səviyyəsinin mövsümi səviyyə tərəddüdlərinə, həmçinin onların amplituda və başvermə fazalarının fəza-zaman paylanmasının tədqiqinə həsr olunmuşdur. Tədqiqatda Envisat, Jason 1 и Jason 2 peyklərinin radar altimetriya məlumtlarından istifadə olunub. Müvafiq peyk trekləri üzrə Xəzər dənizi akvatoriyasının müxtəlif ərazilərində mövsümi səviyyə tərəddüdlərinin orta çoxillik amplitudaları və onların fazaları müəyyənləşdirilmiş, həmçinin Volqa çayı axımının onlara mümkün təsiri araşdırılmışdır. Tədqiqatın nəticələrinə əsasən müəyyənləşdirilmişdir ki, Şimali Xəzərdə dəniz səviyyəsinin mövsümi dəyişmələrinin amplitudaları Cənubi Xəzərə nisbətən daha böyükdür. Belə bir fərq dənizin şərq və qərb əraziləri üçün də mövcuddur. Dənizin səviyyə dəyişilmə amplitudalarının ən erkən fazaları may ayında Şimali Xəzərdə, Volqa çayının deltasından aşağıda, dənizin qalan hissələrində isə nəzərəçarpacaq dərəcədə sonra - iyun-iyul aylarında qeydə alınır. Beləliklə, göstərilmişdir ki, dənizin şimal əraziləri Volqa çayı axımına daha həssasdır və cənuba doğru bu təsir tədricən azalır və digər amillər üstünlük təşkil etməyə başlayır (buxarlanma, atmosfer yağıntıları). Tədqiqatda alınan nəticələrin səbəbləri məqalədə müzakirə olunur.

Açar sözlor: Xəzər dənizi, Volqa çayl, peyk altimetriyası, trek, Jason 1-2, ENVISAT, amplitude, faza, dəniz, saviyyasi 